\title{
Knowledge, Practice and Attitude towards Epilepsy and Associated Factors among Adults in Goncha Siso Enesie Woreda Rural Kebeles, East Gojjam, Ethiopia 2016
}

\author{
Haymanot Zeleke ${ }^{1 *}$, Tenaw Gualu ${ }^{1}$, Yewbmirt Sharew ${ }^{2}$ and Girma Alem
}

${ }^{1}$ Department of Nursing, College of Medicine and Health Sciences, Debre Markos University, Ethiopia

${ }^{2}$ Department of Midwifery, College of Medicine and Health Sciences, Debre Markos University, Ethiopia

*Corresponding author: Zeleke H, Department of Nursing, College of Medicine and Health Sciences, Debre Markos University, Ethiopia, Tel: +251910371389; E-mail: haymanotzeleke89@gmail.com

Received date: May 18, 2018; Accepted date: June 07, 2018; Published date: June 13, 2018

Copyright: ( 2018 Zeleke $\mathrm{H}$, et al. This is an open-access article distributed under the terms of the Creative Commons Attribution License, which permits unrestricted use, distribution, and reproduction in any medium, provided the original author and source are credited.

\begin{abstract}
Back ground: Epilepsy is one of common neurological disorder in developing countries. Epilepsy affects 50 million people worldwide, and $80 \%$ of them live in the developing world. Epilepsy is one of stigmatizing problem with social, physical, economical and psychological effects on the patient as well as on the family.
\end{abstract}

Objective: To assess Knowledge, Practice and Attitude about Epilepsy and associated factors among Adults in Goncha Siso EnesieWoreda Rural Kebeles, East Gojjam, Ethiopia, 2016.

Method: Community based cross-sectional study design was used. The study was conducted from 2 September 2016 to 24 October 2016. In this study, sample size was 634 households from randomly selected kebele. To assess the relationship of factors and with the dependent variables multiple logistic regression analysis was performed.

Result: A total of 600 respondents were interviewed. This made the response rate to be $94.6 \%$. One hundred percent of participants replied as they heard about Epilepsy from different sources previously. Even though they have awareness, about $285(47.5 \%$ ) have inadequate knowledge, $379(63.2 \%)$ poor Practice, $206(34.3 \%$ ) have unfavorable attitude towards epilepsy. Participants who have educational status of college and above are 3.5 times have favorable attitude than participants who could not read and write.

Conclusion: The main finding of this study indicates medium adequate knowledge, high poor Practice and high favorable attitude about epilepsy. The findings indicate, they were familiar with epilepsy, yet there is still problem with practice. Determinate variables for knowledge are educational level, residency and walking time between home and health institution and for practice educational status and family role are significant. Educational status also affects attitude of participants. All stalk holders of Goncha Siso Enesie Woreda and all health institutions shall work integrated on creation of awareness on interventions which are important when they encounter epileptic patient.

Keywords: Epilepsy; Knowledge; Practice and attitude

\section{Introduction}

Chronic non-communicable diseases (NCDs) are an increasingly important health care problem in developing countries and neuropsychiatry disorders account for more than a quarter of the global burden of disease [1]. Mental disorders are now widely recognized as a major contributor to the global burden of disease [2]. From this, epilepsy is one of the most common and serious brain disorders in the world. It affects at least 50 million people in the world [3].

People with epilepsy have increased morbidity related to fractures, scalding, bruising occurring directly as result of seizures. Sudden death, trauma, suicide, pneumonia, and status epilepticus have been identified as being more common in people with epilepsy [4,5]. But cost effective epilepsy treatments are available and an accurate diagnosis can be made without technological equipment [6] thus it is possible to minimize such complication. It is a treatable condition and relatively cheap medication is available, however the treatment gap in developing countries remains very high [3]. People with untreated epilepsy face potentially devastating social consequences and poor health outcomes which are considered as public health issue. Due to stigma, many persons with epilepsy have lower employment, education levels and lower socioeconomic status [6,7]. In rural Ethiopia, patients with epilepsy prefers to take traditional medicines, taking holy water and praying in the religious places since they consider the illness is due to evil spirit [3] also the incidence in rural part of Ethiopia is high [8]. Their knowledge as well as attitude can affect treatment and intervention options (practices) for those who have epilepsy disorder. For whom who have epilepsy to get treatment and decrease treatment gab as well as to get first aid interventions, it is important to assess knowledge, practice and attitude of community about epilepsy. Even there is no enough data about knowledge, practice and attitude of community about epilepsy.

\section{Objectives of this study were}

- To determine the level of adults' knowledge towards epilepsy 
Citation: Zeleke H, Gualu T, Sharew Y, Alem G (2018) Knowledge, Practice and Attitude towards Epilepsy and Associated Factors among Adults in Goncha Siso Enesie Woreda Rural Kebeles, East Gojjam, Ethiopia 2016. Epilepsy J 4: 1000126. doi:10.4172/2472-0895.1000126

Page 2 of 8

- To determine adults' practice towards epileptic patient

- To assess the attitude of adults towards epilepsy

- To identify factors associated with knowledge of adults towards Epilepsy

- To identify factors associated with attitude of adults towards Epilepsy

- To identify factors associated with Practice of adults towards Epilepsy

\section{Materials and Methods}

Community based cross-sectional study design was used. The study was conducted in Goncha Siso Enesie woreda which has a population of 165,218 (source from 2005 woreda health office report). This woreda has 36 rural kebele and had 39067 households. The woreda is found in East Gojjam zone. It is $380 \mathrm{Km}$ far from Addis Ababa, the capital city of Ethiopia and $165 \mathrm{Km}$ away from Bahr Dar which is the capital city of Amhara regional state. The study was conducted from 2 September 2016 to 24 October 2016.
Inclusion criteria were all adults aged 18 years in Goncha Siso Enesie woreda. The exclusion criteria were adults who was sick and who lived within the woreda less than 6 months, Adults who were health professionals.

The sample size was determined by the assumption that $50 \%$ of Practice with 5\% marginal error and 95\% CI $(\alpha=0.05)$ and none response rate of $10 \%$ finally sample size was 634 . Multi stage stratum sampling technique was used to get the required study subjects. From total rural kebeles of Goncha Siso Enesie Woreda seven rural kebeles was selected by simple random sampling technique and farther simple random sampling was used to select Gottes. The sample size was allocated for study area using population proportion technique to each selected Gotte. After mapping the houses, the first household was selected by lottery method then other were selected every $\mathrm{K}$ after calculating $\mathrm{K}$. In the presence of both households (mother and father) during data collection period one of them was selected by lottery method (Figure 1).

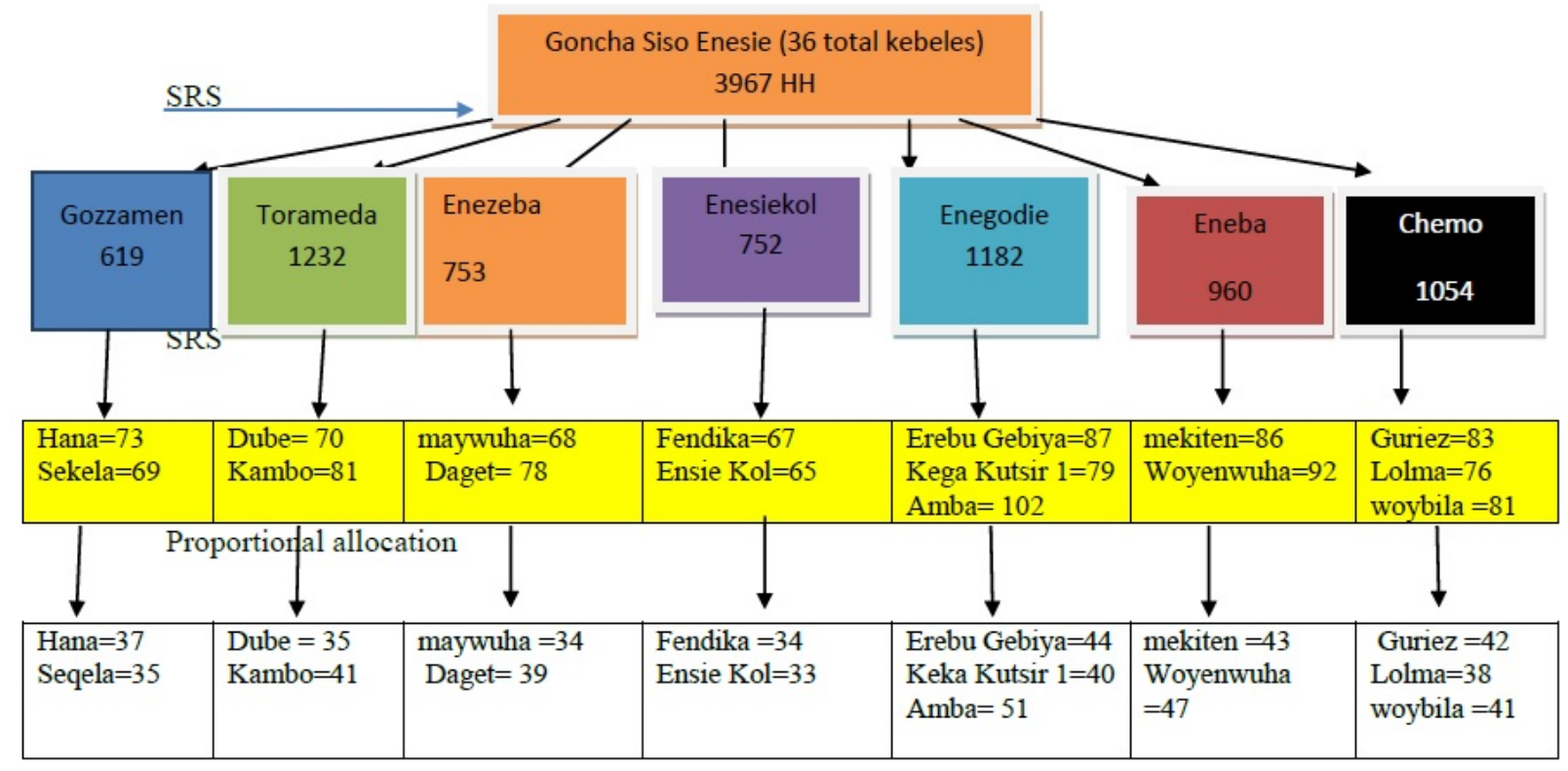

$\mathrm{N}=634$ household

Figure 1: Schematic presentation of sampling procedure.

A structured questionnaire was used to assess the knowledge, attitude and practice of the community regarding epilepsy which was adopted and modified from different literatures [9-23]. The questionnaire has four parts; the first section enquired about personal data including age, sex, ethnicity, religion, marital status, educational level and occupation; the second part elicit knowledge of existence of epilepsy in the community, knowledge of its causal factors, knowledge of whether the disease is transmissible or not, what is to be done when a seizure occurs and awareness and preference of treatment option; while the third part explored the attitudes of the respondents towards epilepsy. The fourth part explored the Practice when seizure occurs.
The English version of the questionnaire was translated into Amharic language, which is the dominant language in the study area. The questionnaire then was translated back to English to check for its consistency. Four BSC Nurses for supervision and twelve health professional workers for data collection were recruited. The interviewers and supervisors were trained for three days to standardize the questionnaire administration. The training was include explanation of the study purpose and the questionnaire, teaching regarding interviewing techniques and correct completion of the structured questionnaire, and ethical considerations in collecting data. The supervisor was monitor the data collection process and close 
Page 3 of 8

supervision of enumerators by the principal investigators was done throughout the data collection period. Pretest was done in the nearest woreda Enebsie Sarmidir woreda on 5\% of the study samples. After the pretest necessary corrections was done to standardize the questionnaire.

Dependent variable was adults' practice towards epileptic patient.

Intermediate variables were Attitude (favorable and unfavorable) and Knowledge (adequate and inadequate).

Independent variables were Socio demographic factors such as age, gender, education, marital status, source of information, distance between home and institution, family role, occupation, religious, and witness to epilepsy patient.

According to this study, "Adequate Knowledgeable" was defined as when respondents scored $>50 \%$ when answering questions related to epilepsy knowledge. The attitude of participants was defined as "favorable" for a score $>50 \%$. Similarly, the study defines practice in epilepsy as "Good Practice" for respondents who scored $>50 \%$.

The collected data was coded, entered, cleaned in Epi data version 3.2 and transferred to SPSS version 20.0 for analysis. Descriptive and inferential statistics was used to present the data. Descriptive statistics like frequency and percentage was used to summarize the sociodemographic characteristics' of the study participants. The dependent variable was not normally distributed $(\mathrm{p}=0.000)$ because of this linear regression was not applied. Binary and multivariable logistic regression was applied. Odds ratio was used to determine if there is association between dependent variable (Practice) and different independent and intermediate variables. Finally multivariable logistic regressions was used to identify significant factors for dependent as well as intermediate variables if $\mathrm{p}<0.2$ in binary logistic regression analysis. $\mathrm{P}$ value of less than 0.05 was considered as significant at $95 \%$ CI in multivariable analysis.

Ethical clearance and approval to conduct this research was obtained from Research and Ethical Review Committee of School of Medicine and Health Science College, The ethical considerations was considered into account the personal and revealing nature of the study, which require that voluntary, informed consent, using the consent form designed for this study, needed to be obtaining from the participants. Prior to administering the questionnaire, the aims and objectives of the study were clearly explained to the participants.

\section{Result}

A total of 600 respondents were interviewed. This made the response rate to be 94 . $6 \%$. Their ages range from 18 to 71 years with the mean of 33.9 years old with standard deviation 12.2. While all the participants are Amhara ethnic group and about $98.8 \%$ are Orthodox Christianity followers (Table 1).

Participants were asked "do they have experienced about Epilepsy?". About $(76.3 \%),(70.7 \%)$ and $(4.3 \%)$ of participants replied as they know someone with epilepsy, have witnessed a seizure before and have family members with epilepsy respectively.

One hundred percent participants were heard about epilepsy from different sources which is displayed in Figure 2 below. Majority they heard from family as well as neighbors.

\section{Level of knowledge towards Epilepsy}

Among the thirteen knowledge questions asked about epilepsy, $285(47.5 \%)$ of the participants answered less than $50 \%$ of the questions correctly and are stated as having inadequate knowledge towards epilepsy.

\begin{tabular}{|c|c|c|c|}
\hline \multicolumn{2}{|l|}{ Variable } & \multirow{2}{*}{$\begin{array}{l}\text { Frequency } \\
309\end{array}$} & \multirow{2}{*}{$\begin{array}{l}\text { Percen } \\
51.5\end{array}$} \\
\hline \multirow{4}{*}{ Age } & 18 to 30 & & \\
\hline & 31 to 45 & 172 & 28.7 \\
\hline & 46 to 60 & 100 & 16.7 \\
\hline & $>60$ & 19 & 3.17 \\
\hline \multirow{2}{*}{ Residence } & Rural town & 219 & 36.5 \\
\hline & Rural & 381 & 63.5 \\
\hline \multirow{2}{*}{ Sex } & Male & 405 & 67.5 \\
\hline & Female & 195 & 32.5 \\
\hline \multirow{5}{*}{ Marital status } & Single & 99 & 16.5 \\
\hline & Married & 401 & 66.8 \\
\hline & Divorced & 60 & 10 \\
\hline & Widowed & 13 & 2.2 \\
\hline & Separated & 27 & 4.5 \\
\hline Ethnicity & Amhara & 600 & 100 \\
\hline \multirow{5}{*}{ Family role } & Father & 254 & 42.3 \\
\hline & Mother & 138 & 23 \\
\hline & Son/daughter & 75 & 12.5 \\
\hline & Grand parent & 13 & 2.17 \\
\hline & Living alone & 120 & 20 \\
\hline \multirow{2}{*}{ Religion } & Orthodox Christianity & 593 & 98.8 \\
\hline & Muslim & 7 & 1.2 \\
\hline \multirow{5}{*}{$\begin{array}{l}\text { Educational } \\
\text { status }\end{array}$} & Not read and write & 161 & 26.8 \\
\hline & Read and write & 177 & 29.5 \\
\hline & primary school & 98 & 16.3 \\
\hline & High school & 83 & 13.8 \\
\hline & College and above & 81 & 13.5 \\
\hline \multirow{6}{*}{ Occupation } & Unemployed & 18 & 3 \\
\hline & $\begin{array}{l}\text { Government } \\
\text { Employee }\end{array}$ & 96 & 16 \\
\hline & Daily Laborer & 67 & 11.2 \\
\hline & Farmer & 390 & 65 \\
\hline & Housewife & 20 & 3.3 \\
\hline & Student & 8 & 1.3 \\
\hline
\end{tabular}


Citation: Zeleke H, Gualu T, Sharew Y, Alem G (2018) Knowledge, Practice and Attitude towards Epilepsy and Associated Factors among Adults in Goncha Siso Enesie Woreda Rural Kebeles, East Gojjam, Ethiopia 2016. Epilepsy J 4: 1000126. doi:10.4172/2472-0895.1000126

Page 4 of 8

\begin{tabular}{|l|l|l|l|}
\hline & Other & 1 & 0.2 \\
\hline $\begin{array}{l}\text { Walking time } \\
\text { between } \\
\text { and } \\
\text { institution }\end{array}$ & $<30$ minutes & 66 & 11 \\
\cline { 2 - 5 } health & 30 to 60 minutes & 324 & 54 \\
\cline { 2 - 5 } & Above 1 hour & 210 & 35 \\
\hline
\end{tabular}

Table 1: Socio demographic characteristics of participants in Goncha Siso Enesie Woreda Rural Kebeles, East Gojjam, Ethiopia, 2016 $(\mathrm{N}=600)$.

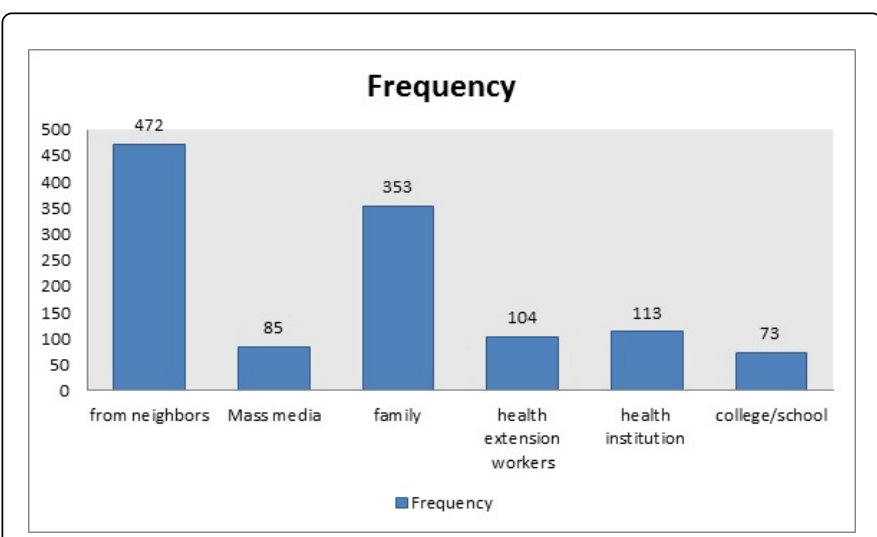

Figure 2: Participants source of information about Epilepsy from different sources in Goncha Siso Enesie Woreda Rural Kebeles, East Gojjam, Ethiopia, 2016.

Majority of participants (78\%) replied that people with epilepsy have a lower IQ than other followed by evil spirit (51.3\%) and punishment from God (51.3\%) (Table 2).

Participants were asked if they know about sign and symptoms of epilepsy. And about (87.7\%), (73\%), (58.8\%), (60.5\%) and 1.7\% replied foaming from the mouth, convulsions, screaming, changes in behavior and others respectively.

\section{Level of practice towards epilepsy of participants}

About 379(63.2\%) participants answered less than 50\% of Practice questions and declare to have poor practice towards epilepsy. What interventions participants would take if they encounter epileptic patient was addressed. Therefore, 537(89.5\%) they will position the patient, sprinkle water over his face $388(67.8 \%$ ) (Figure 3 ).

\section{Attitude towards epilepsy patient}

Among the total respondents, 206(34.3\%) have unfavorable attitude towards epilepsy which is below or equal to the mean value of attitude questions $(<32)$ (Table 3).

\section{Number of participants who have good and poor practice based on distance, sex, residence, knowledge and attitude of Goncha Siso Enesie Woreda Rural Kebeles, East Gojjam, Ethiopia, $2016(n=600)$.}

Participants who have adequate knowledge proportionally have good practice which means more knowledgeable the more have good

practice when they encountered epileptic patient. But sex, residence, distance and attitude seams equal proportion within their categories (Figure 4).

\begin{tabular}{|c|c|c|c|}
\hline \multicolumn{2}{|l|}{ Questions } & $\begin{array}{l}\text { Positive } \\
\text { response No }\end{array}$ & $\begin{array}{l}\text { Positive } \\
\text { response (\%) }\end{array}$ \\
\hline \multicolumn{2}{|c|}{ Is epilepsy is a form of insanity? } & 265 & 44.2 \\
\hline \multicolumn{2}{|c|}{$\begin{array}{l}\text { Do people with epilepsy have a lower IQ } \\
\text { than other people who do not? }\end{array}$} & 468 & 78 \\
\hline \multicolumn{2}{|c|}{$\begin{array}{l}\text { Is epilepsy is treatable with modern } \\
\text { medicine? }\end{array}$} & 286 & 47.7 \\
\hline \multicolumn{2}{|l|}{ Can Epilepsy be cured? } & 170 & 28.3 \\
\hline \multicolumn{2}{|c|}{ Is epilepsy a contagious disease? } & 58 & 9.7 \\
\hline \multicolumn{2}{|l|}{ Congenital } & 64 & 10.7 \\
\hline \multicolumn{2}{|l|}{ Hereditary } & 46 & 7.7 \\
\hline \multicolumn{2}{|l|}{ Witchcraft } & 189 & 31.5 \\
\hline \multicolumn{2}{|l|}{ Evil spirit } & 308 & 51.3 \\
\hline \multicolumn{2}{|l|}{ Brain disease (trauma) } & 145 & 24.2 \\
\hline \multicolumn{2}{|l|}{ Punishment from God } & 308 & 51.3 \\
\hline \multicolumn{2}{|l|}{ Blood disorder } & 51 & 8.5 \\
\hline \multirow{2}{*}{$\begin{array}{l}\text { Over all knowledge } \\
\text { of participants }\end{array}$} & poor knowledge & 285 & 47.5 \\
\hline & good knowledge & 315 & 52.5 \\
\hline
\end{tabular}

Table 2: Level of knowledge of participants towards epilepsy in Goncha Siso Enesie Woreda Rural Kebeles, East Gojjam, Ethiopia, 2016 $(\mathrm{N}=600)$.

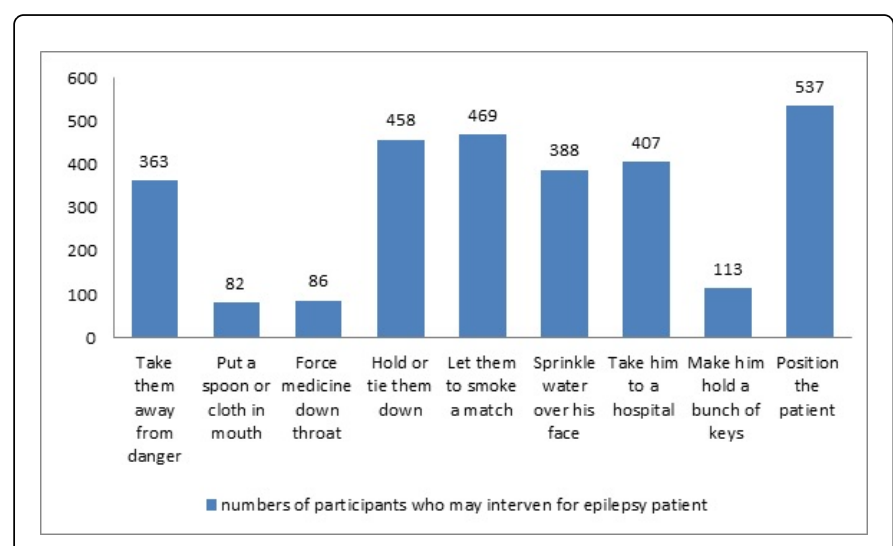

Figure 3: What interventions participant would take if they encounter epileptic patient in Goncha Siso Enesie Woreda Rural Kebeles, East Gojjam, Ethiopia, 2016.

\section{Factors associated with Knowledge, practice and attitude of adults towards Epilepsy}

Those variables which have $\mathrm{p}<0.2$ in binary logistic regression analysis undergo multivariable logistic regressions analysis. Finally, $\mathrm{P}$ value of less than 0.05 was considered as factor. 
Citation: Zeleke H, Gualu T, Sharew Y, Alem G (2018) Knowledge, Practice and Attitude towards Epilepsy and Associated Factors among Adults in Goncha Siso Enesie Woreda Rural Kebeles, East Gojjam, Ethiopia 2016. Epilepsy J 4: 1000126. doi:10.4172/2472-0895.1000126

Page 5 of 8

\begin{tabular}{|c|c|c|c|c|c|}
\hline Variable & $\begin{array}{l}\text { Strongly } \\
\text { disagree }\end{array}$ & Disagree & Neutral & Agree & $\begin{array}{l}\text { Strongly } \\
\text { agree }\end{array}$ \\
\hline $\begin{array}{lr}1 . & \text { Could } \\
\text { people } & \text { with } \\
\text { epilepsy } & \text { get } \\
\text { married } & \end{array}$ & $157(26.2)$ & $141(23.5)$ & $26(4.3)$ & $\begin{array}{l}134 \\
(22.3)\end{array}$ & $142(23.7)$ \\
\hline $\begin{array}{l}\text { 2. Would you } \\
\text { allow for your } \\
\text { child to marry } \\
\text { someone with } \\
\text { epilepsy }\end{array}$ & $254(42.3)$ & $175(29.2)$ & $52(8.7)$ & $58(9.7)$ & $61(10.2)$ \\
\hline $\begin{array}{l}\text { 3. If you were } \\
\text { an employer } \\
\text { would you hire } \\
\text { someone with } \\
\text { epilepsy }\end{array}$ & $250(41.7)$ & $179(29.8)$ & $46(7.7)$ & $70(11.7)$ & $55(9.2)$ \\
\hline $\begin{array}{lr}4 . & \text { Could } \\
\text { people } & \text { with } \\
\text { epilepsy } & \text { have } \\
\text { children } & \end{array}$ & $154(25.7)$ & $68(11.3)$ & $46(7.7)$ & $\begin{array}{l}254 \\
(42.3)\end{array}$ & $78(13.0)$ \\
\hline $\begin{array}{l}\text { 5. Would you } \\
\text { allow to your } \\
\text { child to play } \\
\text { with them }\end{array}$ & $184(30.7)$ & $113(18.8)$ & $38(6.3)$ & $\begin{array}{l}202 \\
(33.7)\end{array}$ & $63(10.5)$ \\
\hline $\begin{array}{l}6 . \quad \text { Does } \\
\text { epilepsy } \\
\text { patients have } \\
\text { a happy life }\end{array}$ & 219 (36.5) & $134(22.3)$ & $50(8.3)$ & $\begin{array}{l}146 \\
(24.3)\end{array}$ & $51(8.5)$ \\
\hline $\begin{array}{l}7 . \\
\text { epilepsy } \\
\text { patients lead a } \\
\text { normal sexual } \\
\text { life }\end{array}$ & $176(29.3)$ & $139(23.2)$ & $\begin{array}{l}79 \\
(13.2)\end{array}$ & $\begin{array}{l}144 \\
(24.0)\end{array}$ & $62(10.3)$ \\
\hline $\begin{array}{l}\text { 8. Do you think } \\
\text { that epilepsy } \\
\text { patients can } \\
\text { be employed }\end{array}$ & 198 (33.0) & $138(23.0)$ & $57(9.5)$ & $\begin{array}{l}155 \\
(25.8)\end{array}$ & $52(8.7)$ \\
\hline $\begin{array}{ll}\text { 9. Will you } \\
\text { reveal your } \\
\text { daughters } \\
\text { case } & \\
\text { Epilepsy } & \\
\text { before } & \\
\text { marriage } & \end{array}$ & $189(31.5)$ & $108(18.0)$ & $\begin{array}{l}70 \\
(11.7)\end{array}$ & $\begin{array}{l}157 \\
(26.2)\end{array}$ & $76(12.7)$ \\
\hline $\begin{array}{l}\text { 10. Do you } \\
\text { think } \\
\text { epilepsy } \\
\text { affects that } \\
\text { education of a } \\
\text { person }\end{array}$ & 111 (18.5) & $64(10.7)$ & $37(6.2)$ & $\begin{array}{l}178 \\
(29.7)\end{array}$ & $210(35.0)$ \\
\hline \multirow{2}{*}{ Attitude } & \multicolumn{2}{|c|}{ Favorable attitude } & \multicolumn{3}{|c|}{$394(65.7 \%)$} \\
\hline & \multicolumn{2}{|c|}{ Unfavorable attitude } & \multicolumn{3}{|c|}{$206(34.3 \%)$} \\
\hline
\end{tabular}

Table 3: Attitude of participants towards epilepsy in Goncha Siso Enesie Woreda Rural Kebeles, East Gojjam, Ethiopia, 2016 (N=600).

Participants who Read and write 2.5 times, High school 1.3 times and College and above 2.3 times have adequate knowledge than not read and write.

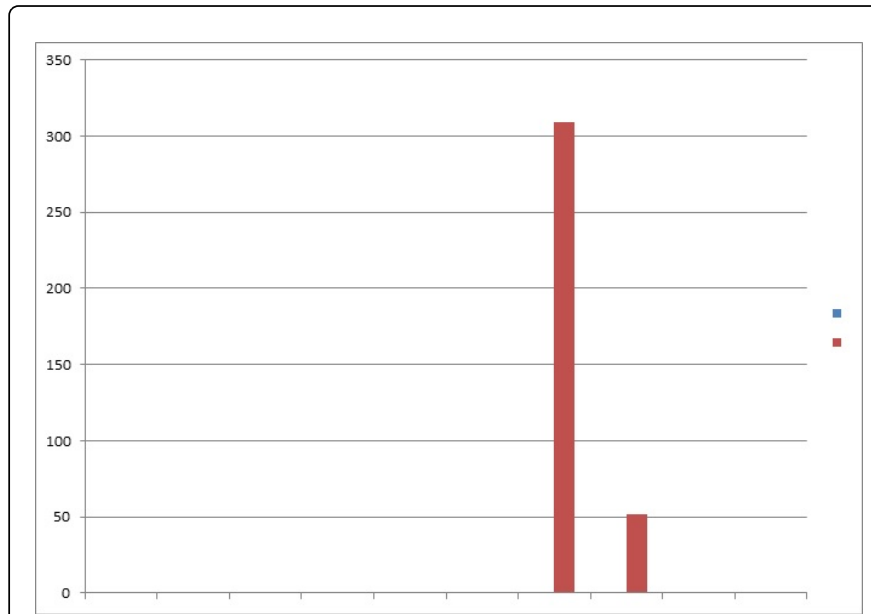

Figure 4: Number of participants who have good and poor practice based on distance, sex, residence, knowledge and attitude of Goncha Siso Enesie Woreda Rural Kebeles, East Gojjam, Ethiopia, $2016(n=600)$.

\begin{tabular}{|c|c|c|c|c|c|}
\hline \multirow{2}{*}{$\begin{array}{l}\text { Independent } \\
\text { variables }\end{array}$} & \multirow[b]{2}{*}{ Category } & \multicolumn{2}{|l|}{ Knowledge } & \multirow[b]{2}{*}{$P$ value } & \multirow{2}{*}{$\begin{array}{l}\text { AOR } \\
(95 \% \\
\text { Cl) }\end{array}$} \\
\hline & & $\begin{array}{l}\text { Inadequate } \\
\%\end{array}$ & $\begin{array}{l}\text { Adequate } \\
\%\end{array}$ & & \\
\hline \multirow{5}{*}{$\begin{array}{l}\text { Educational } \\
\text { status }\end{array}$} & $\begin{array}{l}\text { Not read } \\
\text { and write }\end{array}$ & 96 & 65 & 0 & 1 \\
\hline & $\begin{array}{l}\text { Read and } \\
\text { write }\end{array}$ & 67 & 110 & 0 & 2.521 \\
\hline & $\begin{array}{l}\text { primary } \\
\text { school }\end{array}$ & 40 & 58 & 0.337 & 0.736 \\
\hline & $\begin{array}{l}\text { High } \\
\text { school }\end{array}$ & 51 & 32 & 0.001 & 1.332 \\
\hline & $\begin{array}{l}\text { College } \\
\text { and above }\end{array}$ & 31 & 50 & 0.002 & 2.313 \\
\hline \multirow{2}{*}{$\begin{array}{l}\text { Walking time } \\
\text { between home } \\
\text { and health } \\
\text { institution }\end{array}$} & $\begin{array}{l}\text { Near } \\
\text { distance }\end{array}$ & 122 & 140 & 0 & 1 \\
\hline & $\begin{array}{l}\text { Far } \\
\text { distance }\end{array}$ & 163 & 175 & 0 & 0.323 \\
\hline \multirow{2}{*}{ Residency } & $\begin{array}{l}\text { Semi-Rural } \\
\text { town }\end{array}$ & 114 & 105 & 0 & 1 \\
\hline & Rural & 171 & 210 & 0.014 & 0.629 \\
\hline
\end{tabular}

Table 4: Associated factors for adequate knowledge of participants towards epilepsy in Goncha Siso Enesie Woreda, East Gojjam, Ethiopia, $2016(\mathrm{~N}=600)$.

Participants who lived far distance from health institutions and rural distance have less likely have adequate knowledge (Table 4).

Participants who have educational status of college and above are 3.5 times have favorable attitude than participants who could not read and write (Table 5). 
Page 6 of 8

\begin{tabular}{|c|c|c|c|c|c|}
\hline \multirow{2}{*}{$\begin{array}{l}\text { Independent } \\
\text { variables }\end{array}$} & \multirow{2}{*}{ Category } & \multicolumn{2}{|l|}{ Attitude } & \multirow{2}{*}{$\begin{array}{l}P \\
\text { value }\end{array}$} & \multirow{2}{*}{\begin{tabular}{ll}
\multicolumn{3}{l}{ Adjusted } \\
OR & $(95 \%$ \\
$\mathrm{Cl})$ &
\end{tabular}} \\
\hline & & Unfavorable & Favorable & & \\
\hline \multirow{5}{*}{$\begin{array}{l}\text { Educational } \\
\text { status }\end{array}$} & $\begin{array}{l}\text { Not read } \\
\text { and write }\end{array}$ & 61 & 100 & 0 & 1 \\
\hline & $\begin{array}{l}\text { Read and } \\
\text { write }\end{array}$ & 55 & 122 & 0.188 & 1.353 \\
\hline & $\begin{array}{l}\text { Primary } \\
\text { school }\end{array}$ & 47 & 51 & 0.112 & 0.662 \\
\hline & $\begin{array}{l}\text { High } \\
\text { school }\end{array}$ & 31 & 52 & 0.934 & 1.023 \\
\hline & $\begin{array}{l}\text { College } \\
\text { and above }\end{array}$ & 12 & 69 & 0 & 3.507 \\
\hline
\end{tabular}

Table 5: Associated factors for attitude of participants' towards epilepsy in Goncha Siso Enesie Woreda, East Gojjam, Ethiopia, 2016 ( $\mathrm{N}=600)$.

\begin{tabular}{|c|c|c|c|c|c|}
\hline \multirow[b]{2}{*}{$\begin{array}{l}\text { Independent } \\
\text { variables }\end{array}$} & \multirow[b]{2}{*}{ Category } & \multicolumn{2}{|c|}{ Practices } & \multirow[b]{2}{*}{$\begin{array}{c}P \\
\text { value }\end{array}$} & \multirow[b]{2}{*}{$\begin{array}{l}\text { AOR } \\
(95 \% \mathrm{Cl})\end{array}$} \\
\hline & & $\begin{array}{l}\text { Poor } \\
\text { (\%) }\end{array}$ & $\begin{array}{l}\text { Good } \\
\text { (\%) }\end{array}$ & & \\
\hline \multirow[b]{3}{*}{$\begin{array}{l}\text { Educational } \\
\text { status }\end{array}$} & Not read and write & 153 & 8 & 0 & 1 \\
\hline & Read and write only & 128 & 49 & 0 & 7.989 \\
\hline & $\begin{array}{l}\text { Primary school or } \\
\text { above }\end{array}$ & 98 & 164 & 0 & 42.419 \\
\hline \multirow[b]{5}{*}{ Family role } & Father & 157 & 97 & 0.07 & 0 \\
\hline & Mother & 101 & 37 & 0.056 & 0.577 \\
\hline & Son/daughter & 39 & 37 & 0.115 & 0.608 \\
\hline & Grand parent & 6 & 6 & 0.67 & 1.362 \\
\hline & Living alone & 73 & 47 & 0.008 & 0.412 \\
\hline
\end{tabular}

Table 6: Associated factors for Practice towards epilepsy in Goncha Siso Enesie Woreda, East Gojjam, Ethiopia, 2016 (N=600).

Participants who have higher educational status strongly affect Practice but living alone less likely affect Practice (Table 6).

\section{Discussion}

The study explored Knowledge, practice and attitude toward epilepsy in rural population through a person to person interview using closed-ended questions. One hundred percent of participants heard about epilepsy which is higher than study at Mekelle (85.70\%). This difference may be the study participants at Mekelle are preparatory schools students and more likely less social active but in this study participants are house holders and majority of participants get information from neighbors and family rather than other source of information [13]. But this study is similar with study which was conducted at south India [9]. It is also higher than among the general public reported in Ethiopia [8], United States 95\% [14] and china 93\% [15]. This high degree of awareness about epilepsy may be related to study period difference, social relationships bond and prevalent in the developing country $80 \%$ of epilepsy lives [6]. This can show there is increasing awareness about the case within 2 and half decays year.

In this study $52.5 \%$ of participants have adequate knowledge. In other study at Sululta Woreda, Oromia, Ethiopia 59.8\% and among adults in a Northern Nigerian urban community $57 \%$ of respondents have adequate knowledge related to epilepsy which is relatively higher than this study $[12,20]$. This difference highly related with difference in methodological (area difference rural and urban). This study showed less level of knowledge while it compares with studies conducted in Karachi, Pakistan (77.5\%) [16] and North of Iran 50\% participants have adequate knowledge and University of Delhi on care givers shows that around $49 \%$ of caregiver reported that they have no knowledge. This is because of those studies were conducted on close family members of people with epilepsy (methodological difference occurred) [21]. Similarly University of Delhi on care givers shows that around $49 \%$ of caregiver reported that they have inadequate knowledge [4] which is relatively the same with this study.

This study generally has less knowledge of epilepsy compared with studies carried out among the general public in Ethiopia (89\%) [8], Cameroon (99.3\%) [17], South Korea (94\%) [18] and among school teachers in Egypt (100\%) [19] The discrepancy might be arising from differences in the methodological and socio-demography.

In this study participants who can read and write 2.5 , high school 3.38 and college and above 1.33 times have adequate knowledge than illiterate (not read and write). Which is supported by study at Sululta Oromo shows that those who have secondary level (AOR 95\% CI, 2) and college level (AOR 95\% CI, 2.43) have positive association with the adequate knowledge about epilepsy [20]. The same finding found on study conducted at Northern Nigerian Urban Community [12]. Even study at Mekelle on students revels that educational level differences have positive association; higher classes are more likely to know someone with epilepsy [13].

In this study participants who have far distance between their home and health institutions, $67.7 \%$ less likely have adequate knowledge than near distance. Also the same result revels at sululta oromia community study have positive association with near distance between the respondents home and health institutions [20].

In this study only $36.8 \%$ of participants have good practices towards epileptic patient. This is similar with study at sululta $33.5 \%$ have good practice [20]. The majority of participants $89.5 \%$ would position the patient and $78.2 \%$ would provide match stick smoke, $14.3 \%$ force some medicine down the patients' throat, $76.3 \%$ hold or tie them and $13.7 \%$ will put a spoon/cloth in the patient's mouth. Study in Mekelle shows that $81.9 \%$ would provide match stick smoke, $27.2 \%$ force some medicine down the patients' throat, and $11.3 \%$ put their head in a toilet hole, $14 \%$ hold or tie them down and $22.8 \%$ putting a spoon/cloth in the patient's mouth [13]. Another study in Cameroon [14] indicates that $41.6 \%$ putting a spoon/cloth in the patient's mouth, $13.4 \%$ holding them down.

Participants who have family role of living alone are $58.8 \%$ less likely have good Practice. Similarly study at Sullulta being living alone is $64 \%$ less likely have good Practice [20]. Participants who have higher educational status positively affect practice. Also educational status positively affects Practice in other study [20]. In this study, about 65.7 $\%$ of the respondents have favorable attitude towards epilepsy. The result is higher than a study done in Oromia region of Ethiopia where $35.6 \%$ have favorable attitude But less than a study done in Jimma University where $70 \%$ and a study in Iran where $87.9 \%$ of the 
Page 7 of 8

respondents have favorable attitude [20-22]. This might be from socio demographic differences among study participants and study time.

The result of this study shows respondents who have college and above education 3.5 times more likely to have favorable attitude towards epilepsy than who can't read and write. The result is congruent with a study done in Oromia region which shows participants who have education levels of secondary and college have favorable attitude about epilepsy compared with those who are illiterate [20]. It is also in line with another study done in Nigeria where literate respondents have more positive attitude towards epilepsy [6].

\section{Conclusion}

The main finding of this study indicates medium adequate knowledge, high poor Practice and high favorable attitude towards epilepsy patients. This means there is improvement in Knowledge and attitude when we see the result with other study. Determinate variables for knowledge are educational level, residency and walking time between home and health institution and for Practice; educational status and family role are significant. Also educational status of participants affects attitude in this study. The findings indicate, they are familiar with epilepsy, yet there is still problem with knowledge, unsafe Practice. Scientifically for all epileptic patient who start seizure; the first intervention is removing danger shall be done. But in this study still participants replied that they may not removing danger from epileptic patient, they might use match smoke to awake epileptic patients. Majority of participants recommend holly water and traditional medicine if they encounter epileptic patient which can be correlated with their thinking of the cause of epilepsy is evil spirit and punishment from God. Therefore, all these may farther increase treatment gab.

\section{Recommendation}

There is a need more widespread dissemination of information to improve Practice.

All stalk holders of Goncha Siso Enesie Woreda and all health institution shall work integrated on creation of awareness on interventions which are important when they encounter epileptic patient. Education is necessary to increase educational status of Goncha Siso Enesie Woreda through different information methods especially for rural rather than semi-rural town residency. Health institutions are required to expand their work to address all Goncha Siso Enesie Woreda community. More information to Goncha Siso Enesie Woreda is required to correct misunderstanding on interventions as well as treatment which are required for seizure is occurred. Observational study is required to investigate how they do/ applied the intervention for epilepsy patients because majority $(70.7 \%)$ of participants have witnessed a seizure and have incorrect practice when they get epilepsy patient. Thus it is possible to minimize treatment gab as well as get appropriate first aid intervention for epileptic patients when they encounter.

\section{Acknowledgement}

We would like to acknowledge Debre Markos University, College of Medicine and Health Science for giving us the chance to study this research. We would like to acknowledge Goncha Siso Enesie Woreda people. We were also thankful for our friends and staffs who support us throughout our work.

\section{References}

1. Shibru BSA, Jilalu A, Martin P (2002) Primary care treatment of epilepsy in Rural Ethiopia. Ethiop J Health Dev 16: 235-240.

2. Olubunmi MB (2009) Attitude towards Epilepsy and Mental Illness in Ekiti State, Nigeria. An Internat Multi-Discipl J 3: 1-12.

3. WHO (2004) The Global Campaign Against Epilepsy "Out of the Shadows".

4. Dung HKS, Kumari S, Gupta M, Raval M, Rajender G (2009) Knowledge, Attitude and Perception of Caregivers of Children with Epilepsy. Delhi Psych J 12.

5. de Boer HM, Mula M, Sander JW (2008) The global burden and stigma of epilepsy. Epilep \& Behav 12: 540-546.

6. Meyer A, Dua T, Ma J, Saxena S, Birbeck G, et al. (2009) Global disparities in the epilepsy treatment gap: a systematic review. Bull World Health Organ 88: 260-266.

7. Newton CR, Garcia HH (2012) Epilepsy in poor regions of the world. The Lancet 380: 1193-1201.

8. Tekle-Haimanot R, Forsgren L, Ekstedt J (1997) Incidence of Epilepsy in Rural Central Ethiopia. Epilepsia 38: 541-546.

9. Radhakrishnan K, Pandian JD, Santhoshkumar T, Thomas SV, Deetha TD, et al. (2000) Prevalence, Knowledge, Attitude, and Practice of Epilepsy in Kerala, South India. 41: 1027-1035.

10. Aragon CE, Hess T, Burneo JG (2009) Knowledge and Attitudes about Epilepsy: A Survey of Dentists in London, Ontario. J Canad Dent Assoc 75: 450.

11. Amira SGI, Hussein A (2009) A study of Knowledge, Attitude, Practice towards Epilepsy among relative of epileptic patients in Khartoum State. Sudanese J Publ Health 4: 4.

12. Kabir MZI, Abubakar IS, Kabir ZS, Farinyaro AU (2005) Knowledge, Atitude and Beliefs about Epilepsy among Adults in a Northern Nigerian Urban Community. Annal Afric Med 4: 107-112.

13. Gedefa M, Wolde T, Solomon G (2012) Knowledge, Attitudes and Practices with respect to Epilepsy among Preparatory School Students in Mekelle city, Ethiopia. Internat J Collabor Res Inter Med \& Pub Heal 4: 203-215.

14. Caveness WF, Gallup GH Jr (1980) A survey of public attitudes toward epilepsy in 1979 with an indication of trends over the past thirty years. Epilepsia 21: 509-518.

15. Lai CW, Huang XS, Lai YH, Zhang ZQ, Liu GJ, et al. (1990) Survey of public awareness, understanding, and attitude toward cpilepsy in Henan Province, China. Epilepsia 31: 182-187.

16. Shafiq M, Tanwir M, Tariq A, Kasi PM, Zafar M, et al. (2007) Public knowledge and attitude in a slum area of Karachi, Pakistan. Seizure 16: 330-337.

17. Njamnshi AK, Tabah EN, Bissek AC, Yepnjio FN, Kuate C, et al. (2010) Knowledge, attitudes and practice with respect to epilepsy among secondary school students in the Kumbo West Health District North West Region Cameroon. Epilepsy Behav 18: 247-253.

18. Yoo JK, Jung KY, Park KW, Lee DH, Lee SK, et al. (2009) Familiarity with, understanding of, and attitudes toward epilepsy among people with epilepsy and healthy controls in South Korea. Epilepsy Behav 16: 260-267.

19. Shehataa GA, Mahranb DG (2010) Knowledge, attitude and practice with respect to epilepsy among school teachers in Assiut city, Egypt. Epilepsy Res 92: 191-200.

20. Teferi J, Shewangizaw Z (2015) Assessment of knowledge, attitude, and practice related to epilepsy:a community based study. Neuropsychiatr Dis Treat 11: 1239-1246.

21. Karimi N, Akbarian SA (2016) Knowledge and Attitude toward Epilepsy of Close Family Members of People with Epilepsy in North of Iran.

22. Lim KS, Lim CH, Tan CT (2011) Attitudes toward epilepsy, a systematic review. Neurol Asia 16: 269-280.

23. Chung K, Ivey SL, Guo W, Chung K, Nguyen C, et al. (2010) Knowledge, Attitudes, and Practice towards Epilepsy (KAPE) Survey of Chinese and Vietnamese College Students in the U.S. Berkel Scient J 13: 39-44. 